\title{
A krónikus lymphoid leukaemia mai kezelésének interdiszciplináris kérdései
}

\author{
Szász Róbert dr. - Illés Árpád dr.
}

\author{
Debreceni Egyetem, Általános Orvostudományi Kar, Belgyógyászati Intézet, Hematológiai Tanszék, Debrecen
}

\begin{abstract}
A Bruton-féle tirozin-kinázt gátló ibrutinib és a B-sejtes lymphoma-2-t gátló venetoklax a krónikus lymphoid leukaemia (CLL) kezelésének egyre korábbi vonalában alkalmazható, és ezek mellett a progressziómentes túlélés növekedése figyelhető meg. A célzott kismolekulákkal végzett kezelés nemcsak a CLL lefolyását, de a betegek gondozását is alapvetően megváltoztatta. A tartósan adagolt orális szerek mellett a betegek nagyobb valószínúséggel jelennek meg a panaszaiknak megfelelő szakrendeléseken. Az új típusú szerek hatásai és mellékhatásai mellett az alapvető gyógyszer-interakciókra is fel kell hívni a figyelmet. Kiemelt fontosságú az ibrutinib hypertoniát provokáló hatása, illetve a 6-16\%-ban megjelenő pitvarfibrilláció. Ez utóbbi ellátását a gyógyszer-interakciókon túl az ibrutinib vérzékenységet okozó hatása is nehezíti. A CLL-lel, illetve annak kezelésével kapcsolatos ismeretek a másodlagos daganatok, néhány gastrointestinalis és bőrgyógyászati betegség megközelítése szempontjából is fontosak. A venetoklax mellett potenciálisan kialakuló tumorlízis-szindróma alkalmanként a nefrológusok bevonását igényli. A betegek gondozása, megfelelő szakszerú ellátása és a betegutak optimalizálása érdekében a háziorvosok, a sürgősségi ellátók és az egyéb szakellátó helyek szoros együttmúködése szükséges szakorvosi konzultáció keretei között.
\end{abstract}

Orv Hetil. 2021; 162(9): 336-343.

Kulcsszavak: krónikus lymphoid leukaemia, ibrutinib, venetoklax, idelaliszib, kezelés

\section{Interdisciplinary approach to the current management of chronic lymphocytic leukemia}

\begin{abstract}
Chronic lymphocytic leukemia (CLL) is ubiquitously treated with novel agents. The Bruton's tyrosine kinase inhibitor ibrutinib and the B-cell lymphoma 2 inhibitor venetoclax can be used increasingly in earlier lines of treatment with improved progression-free survival. Treatment with targeted small molecules fundamentally changed not only the course of CLL but also the care of patients. With the administration of long-term oral medications, patients are more likely to show up at specialist clinics that match their complaints. In addition to the effects and side effects of the new drugs, attention should also be drawn to basic drug interactions. The effect of ibrutinib on blood pressure and the ability to provoke atrial fibrillation in $6-16 \%$ of cases are of paramount importance. In addition to drug interactions, the treatment of the latter is also complicated by the hemorrhagic effect of ibrutinib. Knowledge on CLL and its treatment is also important in the approach to secondary tumors, some gastrointestinal and dermatological diseases. The potential for tumor lysis syndrome of venetoclax requires close collaboration with nephrologists. In order to provide appropriate professional care and optimize patient pathways, close co-operation between GPs, emergency care providers and other specialist care facilities is required within the framework of professional consultation.
\end{abstract}

Keywords: chronic lymphocytic leukemia, ibrutinib, venetoclax, idelalisib, therapy

Szász R, Illés Á. [Interdisciplinary approach to the current management of chronic lymphocytic leukemia]. Orv Hetil. 2021; 162(9): 336-343.

(Beérkezett: 2020. június 10.; elfogadva: 2020. augusztus 26.)

\section{Rövidítések}

AUC $=$ (area under the curve $)$ görbe alatti terület; $\mathrm{BCL} 2=$ (B-cell lymphoma 2) B-sejtes lymphoma-2; BCR $=(\mathrm{B}$-cell receptor) B-sejt-receptor; $\mathrm{BTK}=$ (Bruton's tyrosine kinase) Bruton-féle tirozin-kináz; CLL = (chronic lymphocytic leukemia) krónikus lymphoid leukaemia; $\mathrm{CMV}=$ cytomegalovirus;
COVID-19 = (coronavirus disease 2019) koronavírus-betegség 2019; COX2 = ciklooxigenáz-2; CT = (computed tomography) számítógépes tomográfia; CYP3A4 = citokróm P450 3A4; HBsAg = HBV-felszíni antigén; $\mathrm{HBV}=$ hepatitis B-vírus; $\mathrm{HCV}=$ hepatitis $\mathrm{C}$-vírus; IGHV = (immunoglobulin heavy chain variable region) az immunglobulin-nehézlánc variábilis 
régiója; IGHV-M = (IGHV mutated) mutációpozitív IGHV; IGHV-U $=($ IGHV unmutated) mutációnegatív IGHV; IVIG = intravénás immunglobulin; $\mathrm{NK}=$ (natural killer $)$ természetes ölő(sejt); PATCH = Pre-hospital Anti-fibrinolytics for Traumatic Coagulopathy and Haemorrhage; PCR = (polymerase chain reaction) polimeráz-láncreakció; PDI $=$ (programmed cell death protein 1) programozott sejthalál-1; PET/ $\mathrm{CT}=$ (positron-emission tomography/computer tomography) pozitronemissziós tomográfiával kombinált számítógépes tomográfia; PI3K = foszfoinozitol-3-kináz; TEC = (tyrosine kinase expressed in hepatocellular carcinoma) májsejtes carcinomában expresszált tirozin-kináz; TP53 = tumorprotein p53

A hematológia mindig élen járt a molekuláris ismeretek gyakorlati hasznosításában. Az elmúlt évtizedben a krónikus lymphoid leukaemiáról (CLL) szerzett ismeretek bővülése új, a CLL-sejtekben ható, a patofiziológiai eltérések korrekcióját célzó gyógyszerek megjelenését eredményezte. A célzott, orálisan alkalmazható kezelések nemcsak a betegség kezelését változtatják meg, hanem a betegutakra is hatással vannak. Ilyen változást hozott a CLL kezelésében előretörő B-sejt-receptor (BCR)-gátlók és a BCL2-inhibitor alkalmazása. A kemoimmunoterápiák korszakában a CLL-es betegek kezelését, a szövődmények kontrollálását és több társbetegség gondozását is a hematológusok végezték. A tartósan szedett tabletták idején azonban a hematológiai vizitek jelentősen megritkulnak, illetve a szakrendelések szúkebb idejére korlátozódnak. Ennek megfelelően a CLL-es betegek gyakrabban jelennek meg a háziorvosuknál és a panaszaiknak megfelelő rendeléseken, ahol a CLL csak egy a számos anamnesztikus adat közül. Mindezek miatt hasznosnak gondoljuk a CLL-nek, illetve jelenlegi gyógyszeres kezelésének egyéb diszciplínákkal való kapcsolódási pontjait feltérképezni.

\section{A krónikus lymphoid leukaemiáról röviden}

A CLL a lymphoid rendszer malignus megbetegedése. A betegség inkompetens, monoklonális lymphocyták akkumulációjával jellemezhető.

A CLL alapvetően az időskor betegsége. A betegség megjelenésének mediánja függ a populáció átlagéletkorától, Magyarországon 70 év körül van. A betegeknek csak 15\%-a 65 év alatti, de a betegség akár a 3. évtizedben is megjelenhet. A CLL a leggyakoribb leukaemia a nyugati országokban. Férfiakban gyakoribb, mint nőkben, a nemek közti megoszlása különböző forrásokra támaszkodva 1,3-1,7 : 1 közötti. Európában a betegség éves incidenciája megközelítóleg 4-6/100 000 a nók és a férfiak tekintetében. A betegség incidenciája a távolkeleti országokban kb. tizedrésze a nyugati országokban észleltnek [1-3]. Nincs bizonyított foglalkozási vagy környezeti ártalom, amely a CLL kialakulásának fokozott rizikójával járna.

A CLL-ben számtalan genetikai eltérés kimutatható, de néhány malignus hematológiai betegséggel ellentét- ben ezek egyike sem egyenes oka a betegségnek, inkább a progressziót befolyásolják. A patogenezis fó tényezői elsősorban a BCR fokozott múködése és az apoptózis gátlása, de a betegség progressziójához vezető „driver” mutációk megjelenése, epigenetikai eltérések jelenléte és a mikrokörnyezet pozitív visszacsatolásai is szerepet játszanak.

A CLL-ben a T- és NK-sejtek múködése is zavart szenved. A defektív B- és T-sejt-múködés következménye az ismert hypogammaglobulinaemia, továbbá az autoimmun haemolyticus anaemia, a thrombocytopenia vagy a tisztavörösvérsejt-aplasia kialakulása. A defektív immunitás fontos következménye az infekciók fokozott veszélye és a másodlagos daganatok megjelenése.

A CLL diagnózisa a legtöbbször rutinvérvétel során észlelt emelkedett lymphocytaszám alapján születik, ennek megfelelően a betegek jelentős része tünetmentes. Szintén gyakori manifesztáció a fájdalmatlan nyirokcsomók megjelenése. A nyirokcsomók néha növekedésnek indulnak, majd spontán regressziót mutatnak, de nem tûnnek el. A leggyakrabban a nyaki régió érintett. A betegek kevesebb mint 10\%-a jelentkezik típusos B-tünetekkel, azok közül is az izzadékonyság, illetve a fogyás dominál. Az alapbetegség okozta láz szinte csak agreszszív lymphomába történő transzformáció esetén fordul elő, melyet Richter-transzformációnak nevezünk. Láz esetén minden hematológiai betegségben, de CLL-ben kiemelten, helyesebb először infekciós szövődményre gondolnunk.

Tekintettel arra, hogy az indolens lymphomák terápiás algoritmusa ma már eltérő, illetve ezek több altípusában megjelenhet leukaemiás vérkép, a pontos diagnózis elengedhetetlen eleme a perifériás vérből végzett áramlási citometria.

A CLL lefolyása nagyon változó. A korai stádiumú betegek egy része soha nem progrediál, így kezelést sem igényel, közel egyharmadukat diagnózis után rövidesen kezelni kell, a betegek jelentős része pedig évek alatt éri el a kezelési indikációt jelentő kritériumokat. A kezelést nem igénylő betegek életkilátásai a korban illesztett populációéival egyezőek. Ez a tény - kiegészítve azzal, hogy a betegség jelen tudásunk szerint nem gyógyítható - vezetett ahhoz a stratégiához, hogy a CLL diagnózisa nem jelenti egyben a kezelés szükségét. A kezelést csak progresszív betegség esetén ajánljuk, ilyenkor múlják felül a kezelésből származó előnyök a kezelés rizikóit.

A progresszív betegség jelei röviden a következők: előrehaladott csontvelő-elégtelenség, masszív splenomegalia, jelentős $(>10 \mathrm{~cm}$ ) lymphadenomegalia, fokozódó lymphocytosis < 6 hónap lymphocytakettőződési idővel, szteroidra nem kellóképpen reagáló autoimmun anaemia és thrombocytopenia, szimptómás extranodalis érintettség (például bőr, vese, tüdő, gerinc), B-tünetek.

A kezelési indikációk ismeretének hiánya felesleges betegutakat generálhat. A rendszeres gondozás alatt álló beteg vizitperiódusa legtöbbször a betegsége súlyosságához igazodik, ritkán fordul elő, hogy két vizit között 
akut kezelési indikáció jelentkezzen. Ez alól kivételt képez a súlyos autoimmun haemolyticus anaemia vagy thrombocytopenia megjelenése.

CLL-ben a genetikai markerek sokasága és azok egyenkénti alacsony frekvenciája nem teszi lehetővé a molekuláris prognosztikai markerek széles körü vizsgálatát. Ajánlott viszont azon legfontosabb prediktív markerek vizsgálata, melyek a különböző típusú terápiákra adott választ előrevetítik. A teljesség igénye nélkül a legfontosabbak:

IGHV: az immunglobulin-nehézlánc variábilis régiójának szomatikus mutációs statusa. A betegségre jellemző, lefolyása során nem változik. A mutációnegatív (IGHV-U) esetek általában hamarabb és gyorsabban progrediálnak, a kemoterápiára adott válaszuk rosszabb, és átlagos túlélésük is rövidebb, mint a mutációpozitív (IGHV-M) eseteké.

TP53-mutáció/17p-deletio: a p53-fehérjét érintő aberrációk kemorezisztenciát okoznak, így CLL-ben a kemoimmunoterápia kontraindikációját jelentik, mivel az új típusú célzott kezelések a p53-útvonal kikerülésével hatnak.

1lq-deletio: szintén kedvezőtlen prognosztikai markernek tekinthető.

Az említett és egyéb prognosztikai markerek részletes ismertetése nem célunk, erről áttekintést az Orvosi Hetilapban Gurbity és mtsai nyújtottak [4].

A CLL kezelési lehetőségei az utóbbi évtizedben jelentősen megváltoztak. Pontos képet kaptunk a kemoimmunoterápiákkal elérhető eredményekről, illetve ezek határairól. A kemoterápiás szerek között szinte kizárólagossá vált a fludarabin és a ciklofoszfamid vagy a bendamusztin, illetve a klórambucil használata. Az immunoterápiás partner pedig egyre gyakrabban az obinutuzumab a rituximab helyett.

A legfontosabb azonban, hogy új, a CLL patomechanizmusának alapvető jelátviteli útjaiba beavatkozó gyógyszerek jelentek meg. A BCR-jelátvitelt gátló szerek közül kiemelt jelentôségú a Bruton-féle tirozin-kinázt (BTK-) gátló ibrutinib és a BCL2 gátlásán keresztül az apoptózist indukáló venetoklax. Mindkét gyógyszer egyre korábbi kezelési vonalakban alkalmazható a sikeres klinikai tanulmányoknak köszönhetően (Resonate, Resonate-2, Murano, CLL14 stb.). Az új klinikai tanulmányok miatt a CLL terápiája évról évre változik, így ennek ismertetése nem tárgya közleményünknek. Alapvető azonban, hogy a TP53-aberrációval jellemezhető, kemoimmunoterápiára nem jól reagáló esetek csak modern szerekkel, ibrutinibbel vagy venetoklaxszal kezelendők. Előnyük a teljes túlélés tekintetében egyértelmú. Az egyéb rossz prognózisú betegek (IGHV-U, llq-deletio) progressziómentes túlélése is kedvezőbb a célzott kezelésekkel. Szintén megállapítható, hogy relabáló és refrakter CLL-ben kemoimmunoterápia már nem ajánlott.

A BCR-útvonalon ható szerek közé tartozik a foszfoinozitol-3-kinázt (PI3K-) gátló idelaliszib és duveliszib is. A PI3K-gátlók mellékhatásprofilja az ibrutinibétól jóval kedvezőtlenebb, emiatt csak ritkán alkalmazzuk őket. Az új szerek széles körú használata mellett azonban egyre több rezisztenciával és intoleranciával találkozhatunk, így a PI3K-gátlók gyakoribb megjelenése várható. $\mathrm{Az}$ újabb BTK-inhibitorok közül említést érdemel az akalabrutinib és a zanabrutinib; ez utóbbinak egyelöre csak köpenysejtes lymphomában van törzskönyve.

A gyakoribb és általunk fontosnak tartott multidiszciplináris ismereteket szakterületenként próbáltuk összefoglalni a teljesség igénye nélkül és természetszerú átfedésekkel.

\section{Cardiovascularis mellékhatások}

A CLL kezelésében többnyire nélkülözzük a cardiotoxicus hatásukról ismert kemoterápiás szereket. Az ibrutinib többszörös cardiovascularis mellékhatásainak ismerete azonban nélkülözhetetlen a betegek ellátása során.

A vérnyomás emelkedése a betegek közel 20\%-ában fordul elő. A gyógyszer elindításakor erre minden beteg figyelmét fel kell hívni, és a háziorvosi rendelőben is ellenőrizni kell. A mellékhatás nem feltétlenül rögtön, de általában egy éven belül jelentkezik. Ennek jelentőségét aláhúzza, hogy személyes tapasztalatunk alapján a betegek vérnyomása még ibrutinibszedés nélkül sem éri el a célértéket, a hematológiai szakrendelésen a betegek által említett panaszok túlnyomó része a hypertoniához köthető. Az ibrutinib a vérnyomácsökkentő kiválasztása szempontjából nem igényel speciális megfontolást. Ugyanakkor ajánlott béta-blokkoló alkalmazása, mivel a betegek 6-10\%-ában, de tartós szedés esetén akár a 16\%ában pitvarfibrilláció vagy ritkábban más ritmuszavar alakulhat ki [5-7]. Ez egyrészt a BTK és egy ibrutinib által gátolt másik fehérje, a TEC-protein-kináz közvetítésével alakul ki. A TEC-fehérje a thrombocyták integrinreceptorainak jelátvitelében vesz részt. Egy másik lehetséges magyarázat a PI3K-Akt jelútvonal gátlásán alapszik. A PI3K-Akt a sejtciklus szabályozása mellett részt vesz a szívizomsejtek növekedésében, metabolizmusában és az intracelluláris homeosztázis szabályozásában is. Stressz alatt a PI3K-Akt útvonal fontos protektív szerepet tölt be, mely ibrutinibhatás alatt kiesik $[8,9]$. Egy másik lehetséges mechanizmus szintén a krónikus PI3K-gátlás következtében megemelkedő késői nátriumáram és a következményes fokozott automácia [10]. Továbbá a már említett hypertonia is hozzájárul a pitvarfibrilláció kialakulásához, amennyiben nincs megfelelően kontrollálva [11].

A pitvarfibrilláció kezelésekor - a szokásos megfontolásokon túl - antikoagulálás esetén a vérzés fokozott kockázatát, ritmuskontroll esetén az ennek megtartását jelentő nehézséget érdemes figyelembe venni. Egyértelmű ajánlás az ibrutinib okozta pitvarfibrilláció menedzselésére nincs, a hematológus és a kardiológus konzultációja a hematológiai és a kardiológiai rizikó egyeztetése miatt elengedhetetlen. Klinikánkon a Sürgősségi Osztály, az 
Intenzív Osztály és a Hematológiai Tanszék szoros együttmúködésével jelentôs tapasztalatot szereztünk ezen betegek ellátásával kapcsolatban. Hemodinamikai instabilitás esetén ritmuskontrollra törekszünk. A cardioversio elvégzésének idejére az ibrutinib felfüggesztése javasolt, hogy a cardioversio eredményességét növeljük, illetve ez az antiarrythmiás szerekkel mutatott gyógyszer-interakciók miatt is fontos. Tartós ritmuskontrollra a béta-blokkolók részesítendők előnyben. Az ibrutinib visszaépítése fokozatosan történik. Frekvenciakontroll esetén, ha a béta-blokkoló hatástalan, kalciumcsatornablokkoló vagy digoxin adható, de a gyógyszer-interakciók miatt csökkentett dózisban [11]. Néhány esetben az ibrutinibkezelés végleges felfüggesztése is szóba jön, ilyen esetekben a venetoklax a választandó szer.

Az antikoagulálás és a thrombocytaaggregáció-gátlás szempontjából szintén fontos tudni, hogy az ibrutinib a BTK és a már említett TEC gátlásán keresztül aszpirinszerü hatással van a vérlemezkékre, mivel ezek a fehérjék a glikoprotein-VI és a glikoprotein-Ib jelátviteli útjához tartoznak.

Az ibrutinib cardiovascularis protektív hatását klinikai tanulmányokban nem vizsgálták, a thrombocytagátló szerek módosításával kapcsolatos ajánlások fiziológiai és állatkíséretes adatokra, illetve a CLL-tanulmányokban szerzett tapasztalatokra támaszkodnak. Az ibrutinib elindításakor a már szedett aszpirin felfüggesztését javasoljuk alacsony vagy közepes cardiovascularis rizikó esetén; az ibrutinib természetesen a prevencióra később indikált aszpirint is helyettesíti. Nagy cardiovascularis rizikó esetén az ibrutinib és kis dózisú, 75-80 mg aszpirin adható, a vérzés kockázatának jelentős növekedése nélkül. Hasonlóképpen kettős thrombocytaaggregáció-gátlás esetén az ibrutinib kiválthatja az aszpirint, de tanulmányok hiányában elfogadottabb más stratégia felállítása. Ha a kettős thrombocytaaggregáció-gátlás tervezetten átmeneti (például fémsztentek esetén), akkor az ibrutinibkezelés halasztható, tartós kezelés esetén alternatív CLLterápia jön szóba. Ezek az esetek mindenképpen konzultációt igényelnek. Szintén járható út az ibrutinib dózisának fokozatos emelése a klinikai hatás és a vérzékenység monitorozása mellett [12]. Az in vitro aggregációmérés ibrutinib esetén is korrelál a klinikai vérzékenységgel, amit saját gyakorlatunkban is meg tudunk erősíteni; ez segíthet a megfelelő thrombocytaaggregáció-gátló kezelés megválasztásában [13-15]. Az ibrutinib thrombocytára kifejtett hatása háromnapos gyógyszerkihagyással jelentős, egyhetes felfüggesztéssel teljes mértékben eliminálható [12].

Hároméves ibrutinibkezelés mellett a betegek több mint felében figyeltek meg vérzéses szövődményt. A súlyos vérzések egyéves incidenciáját pedig 4-8\% közöttinek találták [16]. A PATCH-tanulmány a thrombocytaaggregáció-gátló mellett bekövetkező koponyaúri vérzések kezelését vizsgálta. Thrombocyta-transzfúzió adása a halálozás emelkedett rizikójával járt a kontrollcsoporthoz képest. Ennek biológia oka nem ismert, illet- ve ibrutinibbel hasonló vizsgálat nem történt, de mindenképpen óvatosságra int a thrombocyta-transzfúzió indikálásakor [17]. A nem központi idegrendszeri vérzések esetén az ibrutinib elhagyása mellett thrombocytatranszfúzió javasolt. A transzfúzió időzítésekor figyelembe kell venni az ibrutinib 3-4 órás féléletidejét.

$\mathrm{Az}$ antikoaguláció a gyógyszer-interakciók miatt igényel figyelmet. Különösen nagy kihívás az antikoagulálás pitvarfibrilláció esetén. Magas stroke-rizikó esetén az ibrutinib mellé antikoagulálás javasolt. A warfarin az ibrutinibhez hasonlóan részlegesen a citokróm P450 3A4 (CYP3A4) enzimen metabolizálódik, kölcsönösen emelve a két gyógyszer vérzést kiváltó rizikóját. Ennek megfelelően warfarin mellett a súlyos vérzések gyakoribb előfordulását (4-10\%) figyelték meg a korai klinikai tanulmányokban $[12,18]$. A K-vitamin-antagonisták ezért kontraindikáltak ibrutinibszedés mellett. Megjegyzendő, hogy a hazánkban elterjedt acenokumarol metabolizmusában a CYP3A4 nem vesz részt, de vizsgálat hiányában az ajánlás erre is vonatkozik. Az általában átmenetileg használt, kis mólsúlyú heparinok biztonsággal alkalmazhatók. A direkt antikoagulánsok mindenképp biztonságosabbak a warfarinnál, de a különböző gyógyszerekkel kapcsolatban pontos adatok nem ismertek [19]. A CYP3A4-metabolizmus alapján a dabigatrán és az edoxaban biztonságosabb lehet, mint például a rivaroxaban és az apixaban, de erôs evidenciával nem rendelkezünk [20]. Egy közelmúltban megjelent közlemény nem provokált vénás trombózis tartós kezelésére épp az apixabant ajánlja, 6 hónap után felére csökkentett dózisban. A direkt trombininhibitor dabigatrán esetén az ibrutinibnek a glikoprotein-P-re kifejtett gátló hatása emelheti az antikoaguláns hatást, de ez a hatás mérsékelten fennáll Xa-faktor-inhibitorok esetén is [11]. Alacsony stroke-rizikó esetén az ibrutinib folytatható, egyéb thrombocytaaggregáció-gátló vagy antikoaguláns adása nélkül. Közepes stroke-rizikó esetén egyéni döntés alapján az ibrutinib magában vagy aszpirinnel kiegészítve adható.

Ha a beteg antikoaguláns kezelés alatt áll, a fenti megfontolások mellett az ibrutinibkezelés elhalasztása is szóba jön, amennyiben az antikoagulálás tervezett hossza és a beteg onkológiai statusa ezt megengedi. Amennyiben a tervezett antikoagulálás a vérzés nagy rizikójával jár, alternatíva lehet a venetoklax alkalmazása.

Az antikoagulálás pontos indikációja és a kezelés hoszszának adekvát megválasztása mindenképp ajánlott. In vitro adatok alapján egyesek itt is - a vérzékenység klinikai monitorozásával - az ibrutinib titrálását javasolják a kiválasztott antikoagulálás mellett [12].

A vérzéses komplikációkat az erős CYP3A4-inhibitorok jelentősen növelik, mivel az ibrutinib vérkoncentrációját a sokszorosára emelik. Ezek a szerek (például klaritromicin, ketokonazol, vorikonazol) kerülendők. Ha szedésük mindenképp indokolt, akkor az ibrutinib átmeneti elhagyása vagy dózisának a redukálása javasolt. A gyenge vagy közepes CYP3A4-gátlók szedése esetén dó- 
ziscsökkentés jön szóba. A megfelelő stratégia kialakításához az alapbetegséget is figyelembe kell venni, így a hematológiai konzultáció nélkülözhetetlen. A nonszteroid gyulladáscsökkentők szedése a hypertonia és a vérzés rizikójával jár. Amennyiben adásuk nem kerülhető el, a szelektív COX2-gátlók részesítendők előnyben.

\section{Laboratóriumi eltérések}

Az ibrutinib egyik fontos tulajdonsága, hogy gátolja a „homing” receptorok múködését, ezáltal a leukaemiás sejtek a lymphoid szervekből a vérkompartmentbe helyeződnek át (ahol pozitív visszacsatolás hiányában idővel apoptózis révén elpusztulnak). A legtöbb esetben a kezelés első 1-2 hónapjában, ritkán fél évig is a fehérvérsejtszám emelkedése látható, ami akár több száz $\mathrm{G} / 1$ is lehet. Ezt semmiképp sem kell a leukaemia romlásaként értékelni, a vérkép egyéb elemei általában már ekkor javulást mutathatnak, és a beteg közérzete javul.

Cytopeniák bármilyen típusú antileukaemiás kezelés mellékhatásaként, illetve az alapbetegség progressziójaként is előfordulhatnak; ezek mérlegelésében a tendencia kimutatása lehet segítségünkre, de alapvetően hematológus kompetenciájába tartozik. Az ibrutinib immuncytopeniát is okozhat [21]. Mint minden fehérvérsejt-eltéréssel járó hematológiai betegség esetén, itt is a kvalitatív vérkép abszolút eltérései a mérvadók a százalékos összetétellel szemben.

A CLL mellett jelentkező akut autoimmun hemolízis, illetve thrombocytopenia igényelhet hematológiai ellátást. Ugyanakkor a vashiányos vérszegénység okának kiderítése CLL-ben is történhet a háziorvos irányításával a megfelelő szakorvosi segítség igénybevételével. A vashiányos vérszegénységet okozó gastrointestinalis tumor kizárása fokozott jelentőségű az emelkedett incidencia miatt.

\section{Gasztroenterológia}

Lymphomatoid papulosis nemcsak köpenysejtes lymphomában, hanem ritkán CLL-ben is elöfordulhat, így ilyenkor a biopsziás minta körültekintő feldolgozása javasolt $[22,23]$.

Az ibrutinib okozta enyhe hasmenés a legtöbb esetben időben limitált, hasfogó szerekkel uralható. Az ibrutinib felfüggesztése nem indokolt, már csak azért sem, mert a gyógyszer újraindításakor ismételten jelentkezhet. Ha tartósan vagy a hétköznapi tevékenységeket jelentősen zavaró mértékben áll fenn, akkor hematológiai konzultáció segítségével az átmeneti dóziscsökkentés megkísérelhető, vagy venetoklaxkezelésre válthatunk.

Az idelaliszib és egyéb, $\delta, \gamma$-PI3K-inhibitorok gastrointestinalis mellékhatásai ettől jóval kifejezettebbek. Hasmenés több mint 40\%-ban fordul elő, a kórházi felvételt igénylő súlyos colitisek aránya megközelítően $10 \%$. A mellékhatást a T-sejtek diszregulációja okozza, a hisztológiai kép intraepithelialis lymphocytosist, neutrophil granulocytás infiltrációt és néhol cryptaabscessust mutat
[24]. A colitis jelentkezése nem korai mellékhatás, ami tovább nehezíti a gyógyszerrel való összefüggésének tisztázását. A colitis infektívnek tünik, de antimikrobás kezelésekre nem reagál. A kezelés legfontosabb eleme a gyógyszer azonnali elhagyása, de emellett sokszor szteroidkezelést is igényel. A megfelelő ellátás nélkül szövődményként megjelenő ileus, perforáció vagy hypovolaemiás sokk miatt halálos kimenetelü is lehet.

A PI3K-inhibitorok gastrointestinalis mellékhatása még a transzaminázok emelkedése, ami akut hepatitist utánozhat, és szintén a kezelés felfüggesztését igényli. A mellékhatások rendeződése után, szoros kontroll mellett a kezelés alacsonyabb dózisban újraindítható. $\mathrm{Az}$ idelaliszibbel szerzett tapasztalataink kedvezőek, a betegek többsége tartós remisszióba került annak ellenére, hogy kezelésüket az észlelt mellékhatások miatt többnyire a tervezett elött megszakítottuk.

Az ibrutinib pH-függő oldhatósága miatt a protonpumpagátlók együttes alkalmazása is aggályokat vetett fel. A maximális vérkoncentráció valóban csökken ugyan, de a hatékonyság szempontjából fontosabb, a gyógyszerexpozíciót kifejező AUC-érték változatlan marad, így a protonpumpagátlók nem kontraindikáltak [25, 26].

Kemoimmunoterápiák indítása előtt kötelező a hepatitisszerológia végzése. HBsAg-pozitivitás esetén a kezelés kontraindikált. Anti-HBC-pozitivitás esetén hepatológus bevonásával HBV-PCR-mérés javasolt. A kezelés csak megfelelő HBV-profilaxis mellett kezdhető el, és folyamatos hepatológiai kontrollt igényel. A profilaxis a kezelés után még legalább egy évig folytatandó az eredmények tükrében. A modern CLL-terápiák mellett a HBV-reaktiváció ritkábban, de szintén elófordul, így ez az ajánlás ugyanúgy érvényben van. A nyugati országokban a BTK-, PI3K-inhibitorok szedése mellett az antivirális gyógyszeres profilaxis alternatívája, a havonta végzett HBV-PCR-teszt terjedt el. Anti-HCV-pozitivitás esetén profilaxist nem alkalmazunk, de szintén javasolt hepatológussal konzultálni az aktív fertőzés fennállásának kizárására [27].

Megjegyzendő, hogy bár a hepatomegalia a CLL ismert manifesztációja, ha splenomegalia nélkül észleljük, érdemes a májmegnagyobbodás okaként alternatív magyarázatot keresni.

\section{Onkológia}

CLL-ben egyes daganatos betegségek emelkedett incidenciája figyelhető meg. Egy retrospektív tanulmányban a CLL hosszú távú túlélői közt a másodlagos malignitások 36\%-ban fordultak elő [28]. A feltételezett okok közül a legvalószínúbb a CLL-ben ismert humorális immunhiány és sejtes immunregulációs zavar, mely az immunológiai felügyelet gyengülésével jár. A CLL-ben megfigyelhető T-sejt-kimerülésre jellemző fenotípus és ennek reverzibilitása intenzív kutatás tárgya. Egyes adatok szerint a hosszú távú ibrutinibkezeléssel a T-sejt-kimerülés visszafordítható [29]. A gyakoribb daganattípu- 
sok CLL-ben is gyakrabban figyelhetők meg (vastagbél, tüdő, emlő, prosztata), az átlagpopulációhoz képest relatíve gyakrabban előforduló daganatok közé pedig a melanoma, az egyéb bőrráktípusok és a fej-nyak régiót érintő rákok tartoznak [28]. Egy hazánkban végzett vizsgálatban Szerafin és mtsai hasonló megállapításokra jutottak. Vizsgálatukban másodlagos malignitást a CLLes betegek 18\%-ában figyeltek meg [30].

A betegek ellátása konzultációt igényel. Ha a CLL nem igényel kezelést, akkor az egyébként is tervezett onkológiai kezelést a CLL nem kontraindikálja. Onkológiai kérésre néha szükség lehet a vérképeltérések rendezésére az onkológiai kezelés megkezdése előtt, ilyenkor a CLL rövid távú kezelése megelőzheti az egyébként előnyt élvező onkológiai kezelést. Kezelést igénylő, illetve kezelés alatt álló CLL esetén mérlegelendő a tervezett onkológiai kezelés típusa, időtartama és a beteg életkilátásai. Amennyiben a beteg vérképe rendezett, a CLL kezelése megszakítható, majd szükség esetén az onkológiai kezelés végeztével folytatható. Két malignus betegség együttes kezelésével nincs megfelelő tapasztalat, de érdemes megemlíteni a venetoklax potenciális kedvező hatását egyes daganatokban $[31,32]$. A PDI fokozott expreszsziója a T-sejt-kimerülés egyik jele, ennek ellenére a CLL kezelésében a PDl-gátlók nem hatékonyak. Szintén nem ismert, hogy mennyire hatékony a CLL-es betegek másodlagos malignitásának checkpointgátlókkal (például PDl-gátlókkal) történő kezelése. Néhány CLL-es beteg metasztatikus melanomájának sikeres kezeléséről számoltak be pembrolizumab és ibrutinib kombinációjával [33].

\section{Börgyógyászat}

A melanoma és a bőrt érintő egyéb rosszindulatú betegségek gyakorisága miatt a CLL-es betegek figyelmét fel kell hívni a bőr önvizsgálatára, illetve időszakosan a kezelőorvos általi ellenőrzés is javasolt. Az ultraibolya-sugárzás elleni védelem kiemelt jelentőségü. A bőrdaganatok kialakulásának relatív rizikója akár 4-szeres lehet [34]. A basalioma kialakulása kifejezetten gyakori, egyes CLLterápiák ezt a rizikót tovább fokozhatják.

A BTK- és PI3k-gátlók mellett előforduló bőrjelenségek széles skálája ismert, az utóbbiak mellett súlyos Stevens-Johnson-szindróma és toxicus epidermalis necrolysis is előfordulhat. A kezelés kapcsán megjelenő bőrjelenségek differenciáldiagnosztikai problémát okozhatnak. A leghasznosabb a gyógyszerek átmeneti felfüggesztése mellett végzett megfigyelés és a bőrbiopszia végzése.

A bőrgyógyászati kórképek közül gyakoriságuk miatt meg kell említenünk a herpes zostert és a scabiest is. A diagnózis felállítása a legtöbbször egyszerü, de mindkettő néha atípusos lokalizációban jelentkezik, a scabies pedig a szocioökonómiai státusztól függetlenül érintheti a betegeket.

\section{Reumatológia}

A CLL az idősek betegsége, így mozgásszervi problémák is halmozottan figyelhetők meg. A CLL és a reumatológiai betegségek között nincs ismert kapcsolat. Az ibrutinib mellett azonban akár 36\%-ban jelentkezhet arthralgia és/vagy myalgia, melynek mechanizmusa nem ismert. Az esetek közel 80\%-a enyhe, és spontán oldódik. Nonszteroid gyulladáscsökkentők szedése vagy az ibrutinib átmeneti elhagyása, illetve a dóziscsökkentés a szokásos stratégia. Néhány, sztatint szedő beteg esetében a sztatinok elhagyása segített [35].

Visszatérő probléma, hogy a CLL diagnózisa miatt az egyébként javasolt fizikoterápiás kezeléseket nem indikálják a feltételezett progresszió veszélye miatt. Jelen tudásunk szerint a fizikoterápiás kezeléseknek nincs szignifikáns hatásuk a CLL progressziójára.

\section{Nefrológia}

A venetoklax a BCL2-gátlás révén azonnali apoptózist vált ki a CLL-es sejtekben. Nagy tumortömeg esetén ez potenciálisan halálos tumorlízis-szindróma kialakulásához vezethet. A gyógyszer adagjának fokozatos titrálása kötelező, ez többnyire sikeresen kivédi a tumorlízis kialakulását. Az ismert mellékhatás elkerülésére a hematológiai kezelés megkezdése előtt a tumorlízis-rizikó becslése és ennek megfelelő profilaxisa javasolt. A nagy kockázatú betegek a kezelés előtt anti-hyperurikaemiás kezelést igényelnek, a folyadékterápia és allopurinol mellett a raszburikáz is indokolt. A klinikai tumorlízis megelőzését szolgálja a kezelés utáni 24 órában többször végzett laboratóriumi vizsgálat is. Laboratóriumi tumorlízis esetén hemodialízis is szóba jön. Ilyenkor a kezelés indikációja nem a vesekárosodás, hanem annak és a tumorlízis egyéb súlyos következményeinek (vesekárosodás, szívmegállás, ritmuszavarok, központi idegrendszeri görcsök) megelőzése. Az ibrutinibbel kapcsolatban nefrológiai mellékhatást nem közöltek, de intézetünk nefrológiai osztályán egy betegünk esetében egyértelműen a gyógyszerhez köthető, súlyos, de reverzibilis vesekárosodást okozó interstitialis nephritist diagnosztizáltak.

A CLL ritkán, de ismerten különböző típusú vesekárosodásokhoz vezethet, melyek közül a leggyakoribb a membranosus glomerulonephritis, a krioglobulin vagy immunkomplex okozta membranoproliferativ glomerulonephritis és 'minimal-change' betegség, de egyéb formákat is leírtak [36]. Kialakulásukhoz nem szükséges progresszív, kezelést igénylő CLL, indolens esetekben is előfordulnak. A diagnózis alapja a vesebiopszia, de a krioglobulinok, a paraprotein és a könnyü láncok vizsgálata is ajánlott. Terápiájában mindenképp szerepet játszik a hematológiai alapbetegség kezelése, melyre immunoterápiával vannak tapasztalatok, esetleg kemoterápiával kiegészítve [37, 38]. Saját gyakorlatunkban egy alkalommal ibrutinibet is sikeresen alkalmaztunk. 


\section{Infektológia}

A fertőzésekkel szembeni fogékonyság a CLL inherens vonása. Két arca van: hematológiai és „immunhiányos” infektológiai betegség.

CLL-ben a szokványos infekciók emelkedett aránya mellett opportunista kórokozók megjelenésével is kell számolnunk. Elmondható, hogy a CLL-es populációban az infekció a vezető halálok. A fertőzések fó oka a már említett humorális és sejtes immunitás zavara. A humorális immunitás állapotáról az immunglobulinok mérése adhat információt. Visszatérő vagy súlyos, antimikrobás szerekre nem kellőképpen reagáló fertőzés esetén IVIGkezelés adandó. Az infekciók gyakoriságát az aktív kezelés tovább fokozza. A kemoterápiás szerek mellett észlelt neutropenia kolóniastimuláló faktor adását indokolja. A célzott kezelések közül az idelaliszib háttérbe szorulását épp a magas infekciós ráta okozta, azonban az ibrutinib esetében is számolni kell leginkább az invazív gombafertőzések gyakoribb megjelenésével [39]. Ennek oka az ibrutinib nem B-sejteket érintő, „off-target” hatásában keresendő, hiszen tartós szedése mellett a B-sejtmúködés és a humorális immunitás javulását figyelték $\operatorname{meg}[40,41]$.

Rutineljárás a kezelés mellett adott Pneumocystis-pneumonia és herpes zoster profilaxis, melyet fél évvel a kezelés befejezése után függesztünk fel, de az anamnézisben szereplő övsömör esetén tartósan adunk.

\section{Pulmonológia}

A tüdőgyógyászattal a fó kapcsolódási pontokat a már részletezett infektológia és onkológia jelenti. Saját tapasztalataink alapján érdemes megemlíteni, hogy a tüdőben észlelt tumorgyanús szolid eltérés szövettani vizsgálata elengedhetetlen. A CLL megjelenhet ugyan szolid tüdőterime formájában, akár annak izolált manifesztációjaként, ez azonban elenyészően ritka, és az esetek túlnyomó többségében tüdőtumorral kell számolnunk. Ellenkezőleg, az általában más okból végzett mellkas-CT-n látott kis mediastinalis nyirokcsomók - egyéb tumorgyanús tüdőeltérés és tünetek hiányában - a CLL manifesztációjának tarthatók, és önmagukban az azonnali tumorirányú kivizsgálást nem indokolják. Kétes esetekben ismételt képalkotó vizsgálatok, esetleg PET/CT vagy a CLL átmeneti kezelése segíthet annak megítélésében, hogy szövettani mintavétel indokolt-e.

$\mathrm{Az}$ idelaliszib a már korábban említett immunregulációs zavar következtében pneumonitist is okozhat. A betegség száraz köhögéssel jelentkezik, melyhez hamarosan légszomj is társul. A képalkotó vizsgálatok interstitialis pneumoniának megfelelő képet mutatnak. Ha nem ismerjük fel időben, a beteg állapota súlyosbodhat, és gépi lélegeztetés válhat szükségessé. A potenciálisan halálos kórkép differenciáldiagnózisát nehezíti, hogy idelaliszibkezelés mellett a teljesen hasonló klinikai megjelenéssel járó cytomegalovirus-pneumonia halmozódá- sát is megfigyelték. A pneumonitis kezelése az idelaliszib felfüggesztése és szükség szerint szteroid adása. A fertőző eredet kizárása érdekében bronchoszkópos mintavétel elvégzése javasolt. Az idelaliszibet szedő betegeket Pneumocystis-profilaxisban kell részesíteni. A cytomegalovirus-fertőzés monitorozására havi rendszerességgel CMV-PCR végzése javasolt.

\section{Következtetés}

A megváltozott kezelési lehetőségek miatt egyre több, krónikus lymphoid leukaemiában szenvedő beteg kezelését tartósan adagolt orális szerekkel végezzük. A kezelt és kezeletlen betegek ugyanakkor koruknál fogva jelentôs komorbiditással rendelkeznek. A CLL mellett fennálló betegségek kezelése az egyre inkább specializálódó társszakmák feladata. Ugyanakkor ez hatékonyan nem képzelhető el az átfedő területek megfelelő ismerete nélkül. A CLL-lel kapcsolatos alapvető ismeretek megszerzése mellett is kiemelt fontosságú, hogy kritikus esetekben a betegek optimális kezelése érdekében a társzakmák képviselői a döntésüket konzultáció keretében hozzák meg.

Anyagi támogatás: A közlemény megírása anyagi támogatásban nem részesült.

Szerzôi munkamegosztás: Sz. R.: Irodalomkutatás, a kézirat elkészítése. I. Á.: A téma felvetése, a kézirat átolvasása és javítása. A cikk végleges változatát mindkét szerző elolvasta és jóváhagyta.

Anyagi érdekeltségek: A szerzőknek nincsenek érdekeltségeik.

\section{Irodalom}

[1] Sant M, Allemani C, Tereanu C, et al. Incidence of hematologic malignancies in Europe by morphologic subtype: results of the HAEMACARE project. Blood 2010; 116: 3724-3734. [Erratum: Blood 2011; 117: 3477.]

[2] Hernández JA, Land KJ, McKenna RW. Leukemias, myeloma, and other lymphoreticular neoplasms. Cancer 1995; 75(1 Suppl): 381-394.

[3] Siegel RL, Miller KD, Jemal A. Cancer statistics, 2020. CA Cancer J Clin. 2020; 70: 7-30.

[4] Gurbity Pálfi T, Fésüs V, Bödör C, et al. State of the art molecular diagnostics and therapy of chronic lymphocytic leukaemia in the era of new targeted therapies. [A krónikus lymphocytás leukaemia korszerú molekuláris diagnosztikája és kezelése az új célzott terápiák korszakában.] Orv Hetil. 2017; 158: 1620-1629. [Hungarian]

[5] Farooqui M, Valdez J, Soto S, et al. Atrial fibrillation in CLL/ SLL patients on ibrutinib. Blood 2015; 126: 2933-2933.

[6] Burger JA, Tedeschi A, Barr PM, et al. Ibrutinib as initial therapy for patients with chronic lymphocytic leukemia. N Engl J Med. 2015; 373: 2425-2437.

[7] Byrd JC, Brown JR, O'Brien S, et al. Ibrutinib versus ofatumum$\mathrm{ab}$ in previously treated chronic lymphoid leukemia. N Engl J Med. 2014; 371: 213-223. 
[8] McMullen JR, Boey EJ, Ooi JY, et al. Ibrutinib increases the risk of atrial fibrillation, potentially through inhibition of cardiac PI3K-Akt signaling. Blood 2014; 124: 3829-3830.

[9] McMullen JR, Amirahmadi F, Woodcock EA, et al. Protective effects of exercise and phosphoinositide 3-kinase $(\mathrm{p} 110 \alpha)$ signaling in dilated and hypertrophic cardiomyopathy. Proc Natl Acad Sci USA 2007; 104: 612-617.

[10] Ezeani M, Elom S. Necessity to evaluate PI3K/Akt signalling pathway in proarrhythmia. Open Heart 2017; 4: e000596.

[11] Ganatra S, Sharma A, Shah S, et al. Ibrutinib-associated atrial fibrillation. JACC Clin Electrophysiol. 2018; 4: 1491-1500.

[12] Shatzel JJ, Olson SR, Tao DL, et al. Ibrutinib-associated bleeding: pathogenesis, management and risk reduction strategies. J Thromb Haemost. 2017; 15: 835-847.

[13] Kazianka L, Drucker C, Skrabs C, et al. Ristocetin-induced platelet aggregation for monitoring of bleeding tendency in CLL treated with ibrutinib. Leukemia 2017; 31: 1117-1122.

[14] Kamel S, Horton L, Ysebaert L, et al. Ibrutinib inhibits collagenmediated but not ADP-mediated platelet aggregation. Leukemia 2015; 29: 783-787.

[15] Levade M, David E, Garcia C, et al. Ibrutinib treatment affects collagen and von Willebrand factor-dependent platelet functions. Blood 2014; 124: 3991-3995.

[16] Wang ML, Blum KA, Martin P, et al. Long-term follow-up of MCL patients treated with single-agent ibrutinib: updated safety and efficacy results. Blood 2015; 126: 739-745.

[17] Baharoglu MI, Cordonnier C, Al-Shahi Salman R, et al. Platelet transfusion versus standard care after acute stroke due to spontaneous cerebral haemorrhage associated with antiplatelet therapy (PATCH): a randomised, open-label, phase 3 trial. Lancet 2016; 387: 2605-2613.

[18] Byrd JC, Furman RR, Coutre SE, et al. Three-year follow-up of treatment-naïve and previously treated patients with CLL and SLL receiving single-agent ibrutinib. Blood 2015; 125: $2497-$ 2506.

[19] Chai-Adisaksopha C, Crowther M, Isayama T, et al. The impact of bleeding complications in patients receiving target-specific oral anticoagulants: a systematic review and meta-analysis. Blood 2014; 124: 2450-2458.

[20] Burnett AE, Mahan CE, Vazquez SR, et al. Guidance for the practical management of the direct oral anticoagulants (DOACs) in VTE treatment. J Thromb Thrombolysis 2016; 41: 206-232.

[21] Suzuki T, Miyakoshi S, Nanba A, et al. A case of chronic lymphocytic leukemia complicated by autoimmune hemolytic anemia due to ibrutinib treatment. J Clin Exp Hematop. 2018; 58: 136140 .

[22] Arkkila PE, Nuutinen H, Ebeling F, et al. Colonic involvement in a patient with chronic lymphocytic leukaemia. Gastroenterol Res Pract. 2008; 2008: 742146.

[23] Green M, Abuamr KM. Chronic lymphocytic leukemia manifesting as colon polyps. Program No. P1543. ACG 2018 Annual Scientific Meeting Abstracts. American College of Gastroenterology, Philadelphia, PA. Am J Gastroenterol. 2018; 113(Suppl l): 888 .

[24] Weidner A-S, Panarelli NC, Gever JT, et al. Idelalisib-associated colitis: histologic findings in 14 patients. Am J Surg Pathol. 2015; 39: 1661-1667.

[25] de Jong J, Sukbuntherng J, Skee D, et al. The effect of food on the pharmacokinetics of oral ibrutinib in healthy participants and patients with chronic lymphocytic leukemia. Cancer Chemother Pharmacol. 2015; 75: 907-916.
[26] de Jong J, Hellemans P, Jiao J, et al. An open-label, sequentialdesign drug interaction study of the effects of omeprazole on the pharmacokinetics of ibrutinib in healthy adults. Blood 2016; 128: 1588 .

[27] Hallek M, Cheson BD, Catovsky D, et al. iwCLL guidelines for diagnosis, indications for treatment, response assessment, and supportive management of CLL. Blood 2018; 131: 2745-2760.

[28] Falchi L, Vitale C, Keating MJ, et al. Incidence and prognostic impact of other cancers in a population of long-term survivors of chronic lymphocytic leukemia. Ann Oncol. 2016; 27: 11001106.

[29] Parry HM, Mirajkar N, Cutmore N, et al. Long-term ibrutinib therapy reverses $\mathrm{CD} 8^{+} \mathrm{T}$ cell exhaustion in B cell chronic lymphocytic leukaemia. Front Immunol. 2019; 10: 2832.

[30] Szerafin L, Jakó J, Varju L. Occurrence of associated tumours in chronic lymphocytic leukaemia. [Társult tumorok előfordulása krónikus lymphoid leukaemiában.] Orv Hetil. 2016; 157: 17521756. [Hungarian]

[31] Whittle JR, Vaillant F, Surgenor E, et al. Dual targeting of CDK4/6 and BCL2 pathways augments tumor response in estrogen receptor-positive breast cancer. Clin Cancer Res. 2020; 26: $4120-4134$.

[32] Lochmann TL, Floros KV, Naseri M, et al. Venetoclax is effective in small-cell lung cancers with high BCL-2 expression. Clin Cancer Res. 2018; 24: 360-369.

[33] Archibald WJ, Meacham PJ, Williams AM, et al. Management of melanoma in patients with chronic lymphocytic leukemia. Leuk Res. 2018; 71: 43-46.

[34] Ishdorj G, Beiggi S, Nugent Z, et al. Risk factors for skin cancer and solid tumors in newly diagnosed patients with chronic lymphocytic leukemia and the impact of skin surveillance on survival. Leuk Lymphoma 2019; 60: 3204-3213.

[35] Rhodes JM, LoRe VA 3rd, Mato AR, et al. Ibrutinib-associated arthralgias/myalgias in patients with chronic lymphocytic leukemia: incidence and impact on clinical outcomes. Clin Lymphoma Myeloma Leuk. 2020; 20: 438-444.el.

[36] Poitou-Verkinder AL, Francois A, Drieux F, et al. The spectrum of kidney pathology in B-cell chronic lymphocytic leukemia/ small lymphocytic lymphoma: a 25 -year multicenter experience. PLOS ONE 2015; 10: e0119156.

[37] Edrees F, Black RM, Leb L, et al. Minimal change disease: a case report of an unusual relationship. Saudi J Kidney Dis Transpl. 2016; 27: 816-820.

[38] Soldarini M, Farina L, Genderini A, et al. A rare case of atypical chronic lymphocytic leukaemia presenting as nephrotic syndrome. BMJ Case Rep. 2017; 2017: bcr-2016-218850.

[39] Anastasopoulou A, DiPippo AJ, Kontoyiannis DP. Non-Aspergillus invasive mould infections in patients treated with ibrutinib. Mycoses 2020; 63: 787-793.

[40] Mangla A, Khare A, Vineeth V, et al. Pleiotropic consequences of Bruton tyrosine kinase deficiency in myeloid lineages lead to poor inflammatory responses. Blood 2004; 104: 1191-1197.

[41] Sun C, Tian X, Lee YS, et al. Partial reconstitution of humoral immunity and fewer infections in patients with chronic lymphocytic leukemia treated with ibrutinib. Blood 2015; 126: 22132219. [Erratum: Blood 2016; 128: 1020.]

(Szász Róbert dr., Debrecen, Nagyerdei krt. 98., 4032 e-mail: szaszr@med.unideb.hu)

A cikk a Creative Commons Attribution 4.0 International License (https://creativecommons.org/licenses/by/4.0/) feltételei szerint publikált Open Access közlemény, melynek szellemében a cikk bármilyen médiumban szabadon felhasználható, megosztható és újraközölhető, feltéve, hogy az eredeti szerző és a közlés helye, illetve a CC License linkje és az esetlegesen végrehajtott módosítások feltüntetésre kerülnek. (SID_1) 